\title{
Functioning Hydraulic and Morphological Sustainability of River Training Works in Bangladesh
}

\author{
Md. Mosiur Rahman ${ }^{1}$, Md. Abu Hena Mostofa Kamal' ${ }^{2}$ and Md. Munsur Rahman ${ }^{1}$ \\ 1. Institute of Water and Flood Management, Bangladesh University of Engineering and Technology (BUET), Dhaka 1000, \\ Bangladesh \\ 2. Department of Civil Engineering, Rajshahi University of Engineering and Technology (RUET), Rajshahi 6204, Bangladesh
}

\begin{abstract}
River dynamics play the most vital role in the socio-economic of the country. These rivers are highly dynamic in nature which causes extensive riverbank erosion. Active river bank erosion and bed scouring, is apprehended to change the scenario, leading to loss of limited valuable land of Bangladesh. River training is being practiced in Bangladesh since 1960s but the process is very expensive especially in the Ganges and the Jamuna Rivers. Five types of river training works were selected at different reaches. Hydro-morphological characteristics of the major rivers are being evaluated not only in engineering concepts but also in socio-economic and environmental aspects. PRA (participatory rural appraisal) tools were applied to evaluate protection safety, hydraulic and hydrological connectivity, ecological and environmental characteristics, causes of failure and social acceptability. This comparative study is being carried out for closing the gap between the modern river training works and in country experience through adaptation of research findings with a view to effectively arresting river bank erosion. Sirajganj Hardpoint, Chandpur Town Protection work and Nakalia Revetment are found to be suitable and effective. A technically suitable structure may not have good social acceptance without IWRM (integrated water resource management).
\end{abstract}

Key words: Sustainability, river training works, river morphology, socio-economic, PRA tools, IWRM.

\section{Introduction}

Bangladesh is a floodplain country, where intensive river networks are the natural lively elements maintaining unique bio-diversity keeping about huge population with the most densely settlement on the earth. River dynamics play the most vital role in the socio-economic of the country. River erosion and accretion, periodical floods, natural adaptation of the society to the hydrological regime as well as its bio-resources from the time immemorial, shows high potential to survive and adapt with new-fangled situations shown in Fig. 1. The erosion and shifting of river courses, loss of land, especially along the Jamuna have long been recognized as a natural problem that affects a sizable population $[1,2]$ in

Corresponding author: Md. Mosiur Rahman, M.Sc., research assistant, research fields: water resources development, integrated water resource management, river hydraulics and river morphology. E-mail: mosiur26ce@yahoo.com.
Bangladesh. The secondary current in a bend of a third order channel of braided river is similar to that of the single thread meandering channel [3]. The influence of secondary currents on flow and sediment dynamics causes meander shifting through river bank erosion and bar formation in typical meandering river [4]. The bank material characteristic along the Jamuna River is fine sand and almost uniform with respect to flow resistance (FAP1, 1993). The overall width of the river exhibits an increasing trend and there is tendency of shifting westwards, especially at the upstream part of the Jamuna river [5, 6]. To mitigate the above problem, historically BWDB (Bangladesh Water Development Board) is being implemented a number of river bank protection structures such as embankments, groins, revetments, spurs, hardpoint etc. [7]. Integrated river basin management is basic requirement of any project. River bank erosion and its protective measures are very important for sustainable 


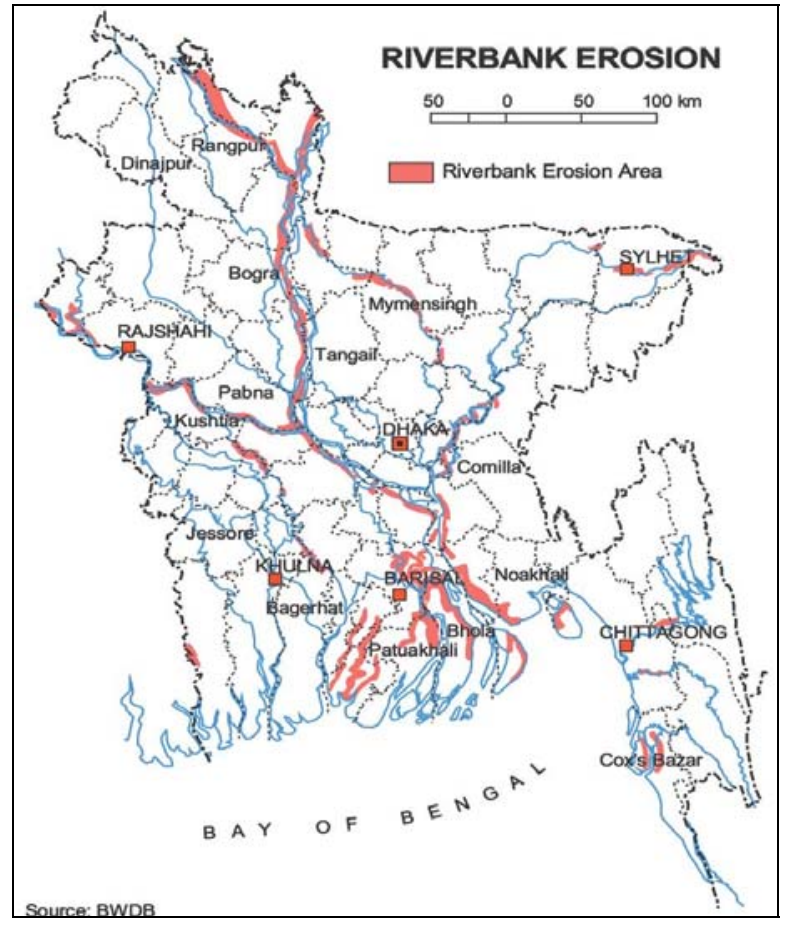

Fig. 1 Location of the erosion prone areas of Bangladesh.

river management. Protective measures may vary as per river characteristics, social attitudes, knowledge and practices of executing agencies. The pattern and intensity of riverbank erosion largely depends on the hydro-morphological characteristics of the river. Bangladesh consist major part of the Bengal Delta. Except a few parts such as Barind Tracts, Madhupur Tracts, Lalmai Hills and Chittagong Hill Tracts, all plain land of the Bangladesh have been formed by the recent sediment, which is high erosion prone by its characteristic.

River training and erosion control is very expensive, especially in the Ganges and the Jamuna Rivers. River training is being practiced in these rivers from 1960s. For example, in order to confine the flow within a single deep channel for navigation or to control the bank erosion to protect city, homestead or valuable lands. Bandalling is practiced for navigation where as revetment works, Hardpoint, Groyne, spur, guide bank, closing of secondary channels are practiced for protection bank erosion. Most of the erosion protection works were either solid spurs or revetment works to protect important locations like Kamarjani,
Fulchari, Sariakandi, Kazipur and Sirajgonj in the Jamuna River. In case of the Ganges River, river training have been used in many places like: Panka Narayanpur, Godagari, Rajshahi, Sarda, Pakshey, Pabna, etc. along the left bank. After the devastating flood in 1988, RSP (river survey project) FAP21 and FAP22 [8] studied river bank erosion problems of the major rivers of Bangladesh. FAP21 selected the critical locations for river training along the right bank of the Jamuna River [9]. During 1996 to 1998 some special protection measures are taken (Sariakandi and Mathurapara hardpoint, Sirajgonj hardpoint and strengthening of Kalitola groyne) engaging foreign consultants and contractors with World Bank Loan. After wards in connection with Jamuna Bridge; Bhuapur Hardpoint and Jamuna Bridge guide banks are constructed by foreign consultants and contractors. These special river training works were very costly in comparison with the protection work done by BWDB $[10,11]$ itself. In spite of the Jamuna River bank protection works, BWDB has done huge erosion protection works throughout the country with revetment, solid or permeable spurs, porcupines along the Ganges, the Padma, the upper and lower Meghna, Teesta, Gumti, Kushiyara, Surma, Mohanada, Atrai, Dharla, Dudkumar and many other rivers.

\section{Methodology}

\subsection{Identification of Method and Selection of Reaches for Actual Field Investigations}

Five types of river bank protection structures usually used were selected. They are shown in Table 1. During field investigations, the technical and social aspects will be taking into considerations of different geo-morphological setting of the country and river systems are shown in Fig. 2.

\subsection{Preparation of Checklist}

A checklist has prepared to carry out the technical and social investigations on selected river training and 
bank protection works. It may be noted that any river training works should consider technical issues as well as social needs.

\subsubsection{Carrying out Technical Investigations}

Types of structures, cost, stability and its performance are mainly governed by the morphological characteristics of the concerned river such as planform, bed material size, scour depth, flow velocities. Most of the structures, except the Chandpur bank protection work, are constructed in the recent past and they are not older than one and a half decades. Planform of the Jamuna is braided and the planform of the Pamda and some reaches of the Ganges vary between braided and meandering. A structure may experience the attack of different intensities of flow. Betil and Enyatpur structures

Table 1 Types of structures and their location studied.

\begin{tabular}{ll}
\hline Type of structures & Name of reaches for structures \\
\hline 1. Hard point & Sirajgonj (Jamuna River) \\
2. Revetment & Chandpur (Padma River), Godagari (Ganges River), Titporal (Jamuna river) \\
(1) with concrete block; (2) with Geo-bag & Pabna (Jamuna River) \\
3. Groyne & Kalitala (Jamuna River) \\
4. RCC Spur & Enayetpur and Betil (Jamuna River), Chapai Nawabganj (Ganges River) \\
5. Bandals & Upstream of the Jamuna Bridge (left bank) \\
\hline
\end{tabular}

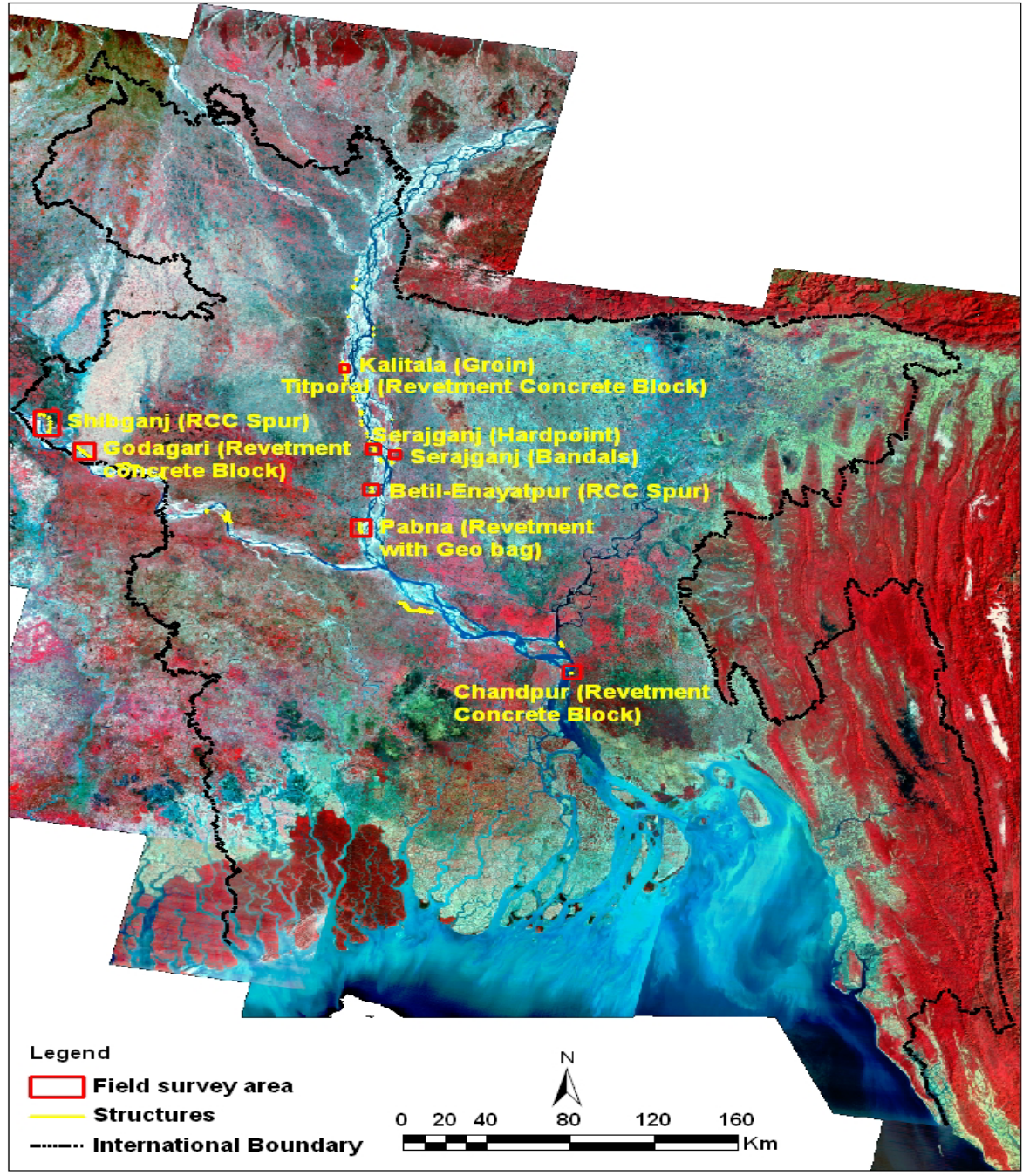

Fig. 2 Location of the studies area. 
were exposed to a smaller channel, while the Sirajganj structure exposed to the flow of a major channel in 2009. It may happen that a few structures never exposed to the attack of main flow of the river during its short life time. In such cases technical performance of such structures could only be evaluated through evaluating the performance of similar structures in the same fluvial environment but that should be exposed to the attack of the main flow for couple of years during its life. To estimate the number of years, a structure exposes to the main flow of the river, time series satellite images available in CEGIS archive were used. Average bankfull width of the channel adjacent to the structure was assessed from the images. Using this width and regime relations derived by FAP 24 for the Jamuna, Ganges and Padma Rivers bankfull discharges of those channels were estimated. Regime relations are:

$$
\begin{aligned}
& W=8.97 Q^{0.57} \quad \text { Jamuna River } \\
& W=9.97 Q^{0.55} \quad \text { Ganges River } \\
& W=4.76 Q^{0.62} \quad \text { Padma River }
\end{aligned}
$$

where, $W$ is bankfull width $(\mathrm{m})$ and $Q$ is bankfull discharge $\left(\mathrm{m}^{3} / \mathrm{s}\right)$. The bankfull discharge as estimated by FAP 24 for the Jamuna, Ganges and Padma Rivers are 50,000, 45,000 and $80,000 \mathrm{~m}^{3} / \mathrm{s}$, respectively.

\subsubsection{Carrying out Socio-economic Investigations}

An important part of this project is to study social needs regarding river training works and bank protection. Social needs also play an important role in the process of river training works of particular area. Local knowledge collected from local people to minimize river erosion risks should be given due consideration and might be a good tool for understanding which kind of river training works should be selected at the erosion prone area. Thus RRA methodology would be applied and checklist would be used, where target would be focused on river erosion process and consequent social responses. In addition, KII (key informant interview) procedures would be followed for cross-checking and improvements of RRA information. Key informants will be the local knowledgeable people like retired engineer, physician, contractor, teacher, union parishad chairman and members, etc..

\subsubsection{Preparation of Matrix}

A matrix is a combination of indicators, which will assist in extraction of field information, compilation and analysis of existing river bank protection and erosion control practices in Bangladesh clearly show their effectiveness in terms of social requirements, and mechanisms of failures and attributes of river bank protection structures. An integrated approach is considered for preparation of matrix and will be based on literature review, expertise evaluation, field investigations for accommodation of cost effectiveness, sustainability, local views, community response, etc. for carrying out comparisons and deriving final conclusions on suitability of those river works.

\section{River Morphology}

\subsection{Discharges}

Bangladesh is a lower riparian country of the three mighty rivers: the Ganges, the Brahmaputra (Jamuna) and the Meghna and total 320 number of rivers flow through the country. These river systems drain a huge catchment area of about 1.72 million $\mathrm{km}^{2}$. The combined average annual discharge of these rivers is about 345,000 $\mathrm{m}^{3} / \mathrm{s}$ and the combined peak discharge in the order of $200,000 \mathrm{~m}^{3} / \mathrm{s}$ [12]. The combined peak discharge becomes higher when flood occur in the Ganges and the Jamuna in the same time. Normally flood in the Jamuna comes earlier than the Ganges.

\subsection{Bed Slopes}

Bangladesh is situated on the water course with gentle slope from north to south. It is situated between the foot of the world's highest mountain Himalaya lies in the North and Bay of Bengal in the south. Water surface slopes of the major rivers are very flat, e.g., average slope of the Ganges is $5 \mathrm{~cm} / \mathrm{km}$ to $6 \mathrm{~cm} / \mathrm{km}$, 
for Jamuna $7 \mathrm{~cm} / \mathrm{km}$ to $9 \mathrm{~cm} / \mathrm{km}$ and lower Meghna it is $3.5 \mathrm{~cm} / \mathrm{km}$ to $4 \mathrm{~cm} / \mathrm{km}$. Water surface slope of the Northern and Eastern rivers are steeper, like Teesta, Dharla, Dudkumar it is $30 \mathrm{~cm} / \mathrm{km}$ to $90 \mathrm{~cm} / \mathrm{km}$.

\subsection{Sediment Discharges}

Rivers in Bangladesh carry huge sediment every year, which make rivers unstable. Table 2 shows estimated volume of sediment carried out by different researchers based on the measurement at different periods. It shows that the estimates of Coleman [13], BWDB [14] and CEGIS [9] for the Jamuna and Ganges Rivers are close to each other and nearly equals to one billion tons per year. Out of this amount one third of sediment consists of fine sand and rest of the sediment consists of silt and clay.

\subsection{Planform}

Planform of the large rivers of Bangladesh such as the Jamuna, Ganges, Padma and Lower Meghna Rivers varies from braided to meandering. For each river planform also varies spatially and temporarily. The Jamuna River is mainly a braided river having length-averaged braiding intensity varying from 2 to 3 [9]. On the other hand, the Ganges is mainly a meandering river with a number of chute channels in some large meandering bends. Planform of the Padma and Lower Meghna River vary from straight to meandering and braided over time. Braiding intensity of the Padam River varies from 1.3 to 2.2.

\section{Structural Sustainability}

\subsection{Characteristics of the Structures}

The hard point including $2.5 \mathrm{~km}$ revetment at Sirajgonj, revetment with concrete block at Titporal, revetment with geo-bag at Nakalia-Bera, revetment concrete block at Chandpur and RCC Spur at Panka-Narayanpur are the defensive structures and revetment with concrete block at Rajshahi, RCC Spur at Betil-Enayetpur and bandals are the offensive structures. The main purpose of these structures is to reduce the flow velocity and minimize the river bank erosion.

\subsection{Failure Mechanism of the Structures}

Revetment concrete block at Chandpur and RCC Spur at Betil-Enayetpur are failed due to local scouring and cause mass failure. It is due to generation of high discharge around the structures. Revetment with Geo-bag at Nakalia-Bera, Revetment concrete block at Rajshahi, RCC Spur at Panka-Narayanpur and Kalitola Groyne are also failed due to local scouring and floodplain erosion. But bandals (temporary structure) failed due to hitting by direct flow and floodplain erosion.

\subsection{People Perceptions}

River training is being practiced in Bangladesh since 1960s. Bandaling is practiced for navigation where as revetment works, hardpoint, groynes/spur,

Table 2 Total suspended sediment load in the Jamuna, Ganges and Padma rivers (Source, CEGIS, 2010).

\begin{tabular}{|c|c|c|c|c|c|c|}
\hline \multirow[b]{2}{*}{ Source } & \multicolumn{2}{|l|}{ Jamuna } & \multicolumn{2}{|l|}{ Ganges } & \multicolumn{2}{|l|}{ Padma } \\
\hline & $\begin{array}{l}\text { Period of } \\
\text { sediment } \\
\text { record }\end{array}$ & $\begin{array}{l}\text { Suspended sediment } \\
\text { (million } \\
\text { tons/yr) }\end{array}$ & $\begin{array}{l}\text { Period } \\
\text { of sediment } \\
\text { record }\end{array}$ & $\begin{array}{l}\text { Suspended } \\
\text { sediment (million } \\
\text { tons/yr) }\end{array}$ & $\begin{array}{l}\text { Period of } \\
\text { sediment record }\end{array}$ & $\begin{array}{l}\text { Suspended } \\
\text { sediment (million } \\
\text { tons/yr) }\end{array}$ \\
\hline $\begin{array}{l}\text { Holeman } \\
\text { (1968) }\end{array}$ & - & 800 & 1874-1879 & 1,600 & - & - \\
\hline $\begin{array}{l}\text { Coleman } \\
\text { (1969) }\end{array}$ & 1958-1962 & 610 & 1958-1962 & 480 & - & - \\
\hline $\begin{array}{l}\text { BWDB } \\
(1972)\end{array}$ & 1966-1969 & 553 & 1966-1969 & 494 & 1966-1969 & 755 \\
\hline $\begin{array}{l}\text { CEGIS } \\
(2010)^{*}\end{array}$ & 1993-1996 & 402 & 1993-1996 & 632 & 1993-1996 & 948 \\
\hline
\end{tabular}

*Analysis was based on the sediment gauging by FAP 24. 
guide bank, closing of secondary channels are practiced for bank protection. Most of the river traianing works were either solid spurs or revetment to protect important locations like Kamarjani, Fulchari, Sariakandi, Kazipur and Sirajgonj in the Jamuna River. In case of the Ganges River, protection structures have been constructed in many places like Panka-Narayanpur, Godagari, Rajshahi, Sarda, Pakshey, Pabna, etc. along the left bank. Hard point is very massive structure. According to local stakeholders, there was no indication of safety and were unsatisfied when the structures had failed. Revetment with Geo-bag at Nakalia-Bera, Revetment concrete block at Chandpur and RCC Spur at Betil, Enayetpur local people are satisfied by its present efficiency. It also increases their level of safety. Local stakeholder also felt safe (upstream) and satisfied considering the present efficiency of the Kalitola Groyne and Bandals structures but it is not strong in nature. Revetment concrete block at Rajshahi and RCC Spur at Panka-Narayanpur, the people felt very poor level of safety because the structure does not work effectively.

\subsection{Ecology of the Adjacent Structures}

According to local stakeholder and fisher man of some specific reaches, fishes were available before construction of hard point including $2.5 \mathrm{~km}$ revetment. But decreased significantly, after construction of the structure at Sirajgonj, revetment with concrete block at Titporal, revetment concrete block at Rajshahi, Kalitola groyne and RCC Spur at Panka-Narayanpur. Fishes are also available with geo-bag at Nakalia, Bera and revetment concrete block at Chandpur before construction. But there were no significant changes after construction of the structures. Small species of various fish are available before and after construction RCC Spur at Betil-Enayetpur but total amount of fish production is reduce. With Bandal structures fishing are more difficult.

\subsection{Economic Activities}

There are direct and indirect advantages of river training works such as hard point. The primary advantage is the fact that local people will be employed. Therefore, hardpoint may be considered as management tool for increasing the public return. The protection structure of Titporal revetment did not create any income, but it prevents flood damage to crops, property and infrastructure over an area of 30,000 ha, inhabited by 4-5 million people. The protection structure of Spur at Chapai Nawabganj (Panka Narayanpur) creates employment opportunities in agricultural sector. Some char lands are formed along the bank of the protection structure. The protection structure of Chandpur town protection work creates employment opportunities in fisheries group. Due to low water and backward water flow simultaneously, different types of fish populations dwell there. At present, the mole head of the revetment is used as an aesthetic place. In the Kalitola Groyne adjacent char land area, community people are poorly benefited by the protection structure. As per opinion of the local people, the bandal structure can save their valuable and fertile agricultural land form erosion to some extent. As a result of deposition of silt, the local people get the opportunity to cultivated rice, wheat, sweet potato, oil seed and pulses in newly deposited land near bank. Cultivation of peanuts in newly deposited char lands is another good option.

\section{Results and Discussions}

The protection work arises a little hope for safety among the local community. The riverine people of Bangladesh always help each other to shift from the affected area during any disaster. Their social bondage is very high. So, community level response is very prompt during any erosion disaster. Now a day, settlement pattern of riverine people is changing (liner to scattered), it is difficult to continue such community response. The socio-economic development depends 
Table 3 Understanding the attributes of river bank protection and erosion control practices (technical).

\begin{tabular}{|c|c|c|c|c|c|c|c|}
\hline Type of structures & Techniques (flow management) & $\begin{array}{l}\text { Construction } \\
\text { materials }\end{array}$ & Manpower & Longevity & Real longevity & $\begin{array}{l}\text { Maintenance cost } \\
\text { (qualitative) }\end{array}$ & $\begin{array}{l}\begin{array}{l}\text { Protection } \\
\text { safety }\end{array} \\
\end{array}$ \\
\hline $\begin{array}{l}\text { 1. Hard point including } 2.5 \mathrm{~km} \\
\text { revetment (Sirajgonj) }\end{array}$ & $\begin{array}{l}\text { Energy dissipation } \\
\text { Flow diversion } \\
\text { (Aggressive mode) }\end{array}$ & $\begin{array}{l}\text { Mainly CC blocks } \\
\text { and geo aprons }\end{array}$ & $\begin{array}{l}0.5 \text { lac man days } \\
\text { (Sirajgonj, Sariakandi, } \\
\text { Kalitola) }\end{array}$ & $\begin{array}{l}\text { As per design } 20 \\
\text { years }\end{array}$ & 10 years & Medium & High \\
\hline \begin{tabular}{|l|} 
2. Revetment \\
with concrete block (Titporal)
\end{tabular} & \begin{tabular}{|l|} 
Scour protection \\
Energy dissipation \\
Flow modification \\
\end{tabular} & $\begin{array}{l}\text { Mainly CC blocks } \\
\text { and geo aprons }\end{array}$ & $\begin{array}{l}0.5 \text { lac man days } \\
\text { (Sirajgonj, Sariakandi, } \\
\text { Kalitola) }\end{array}$ & $\begin{array}{l}\text { As per design } 20 \\
\text { years }\end{array}$ & 2 years & High & Medium \\
\hline $\begin{array}{l}\text { 3. Revetment } \\
\text { with Geo-bag } \\
\text { (Nakalia, Bera) }\end{array}$ & \begin{tabular}{|l|} 
Scour protection \\
Energy dissipation \\
Flow modification
\end{tabular} & $\begin{array}{l}\text { CC blocks and } \\
\text { sand-filled geo textile } \\
\text { bags }\end{array}$ & Not specified & $\begin{array}{l}\text { As per design } 20 \\
\text { years }\end{array}$ & Smoothly operated & low & High \\
\hline $\begin{array}{l}\text { 4. Revetment concrete block } \\
\text { (Rajshahi) }\end{array}$ & $\begin{array}{l}\text { Reduce flow velocity and } \\
\text { divert the flow to the main } \\
\text { channel }\end{array}$ & $\begin{array}{l}\text { Mainly CC blocks } \\
\text { and geo aprons }\end{array}$ & Not specified & $\begin{array}{l}\text { As per design } 20 \\
\text { years }\end{array}$ & 1 year & Medium & Medium \\
\hline $\begin{array}{l}\text { 5. Revetment concrete block } \\
\text { (Chandpur) }\end{array}$ & $\begin{array}{l}\text { Reduce flow velocity and } \\
\text { divert the flow to the main } \\
\text { channel }\end{array}$ & $\begin{array}{l}\text { Mainly CC blocks } \\
\text { and geo aprons }\end{array}$ & Not specified & $\begin{array}{l}\text { As per design } 20 \\
\text { years }\end{array}$ & $\begin{array}{l}\text { Phase I: } 20 \text { years; } \\
\text { Phase II: } 2 \text { years }\end{array}$ & Medium & High \\
\hline 6. Groyne (kalitola) & $\begin{array}{l}\text { Flow diversion } \\
\text { (aggressive mode) }\end{array}$ & $\begin{array}{l}\text { Mud filling and CC } \\
\text { block }\end{array}$ & $\begin{array}{l}0.5 \text { lac man days } \\
\text { (Sirajgonj, Sariakandi, } \\
\text { Kalitola) }\end{array}$ & $\begin{array}{l}\text { As per design } 20 \\
\text { years }\end{array}$ & 10 years & Very high & High \\
\hline $\begin{array}{l}\text { 7. RCC Spur } \\
\text { (Betil, Enayetpur) }\end{array}$ & $\begin{array}{l}\text { Flow diversion } \\
\text { (aggressive mode) }\end{array}$ & $\begin{array}{l}\text { RCC piling, mud } \\
\text { filing and CC block }\end{array}$ & Not specified & $\begin{array}{l}\text { As per design } 20 \\
\text { years }\end{array}$ & 6 years & Medium & Low \\
\hline $\begin{array}{l}\text { 8. RCC Spur } \\
\text { (Panka -Narayanpur) }\end{array}$ & $\begin{array}{l}\text { Flow diversion } \\
\text { (aggressive mode) }\end{array}$ & $\begin{array}{l}\text { RCC piling, mud } \\
\text { filing and CC block }\end{array}$ & Not specified & $\begin{array}{l}\text { As per design } 20 \\
\text { years }\end{array}$ & 2 years & Medium & low \\
\hline 9. Bandals & $\begin{array}{l}\text { Flow diversion (conservative } \\
\text { mode) }\end{array}$ & $\begin{array}{l}\text { Bamboo and bamboo } \\
\text { mat }\end{array}$ & 70 person/daily & 1 year (experimental) & 1 year & Not specified & Very low \\
\hline
\end{tabular}

Note: The cost of the hard point including $2.5 \mathrm{~km}$ revetment (Sirajgonj) may defer to the cost that found from literature review. 
Table 4 Dynamics of river processes (natural).

\begin{tabular}{|c|c|c|c|c|c|c|}
\hline \multirow{2}{*}{$\begin{array}{l}\text { Type of } \\
\text { structures }\end{array}$} & \multicolumn{2}{|c|}{ River characteristics (hydraulic) } & \multicolumn{2}{|c|}{$\begin{array}{l}\text { River connectivity with natural setting (floodplain, } \\
\text { town, river networks, etc.) }\end{array}$} & \multicolumn{2}{|c|}{$\begin{array}{c}\text { Bio-habitat (ecological and environmental } \\
\text { considerations) }\end{array}$} \\
\hline & Pre-intervention & Post-intervention & Pre-intervention & Post-intervention & Pre-intervention & Post-intervention \\
\hline $\begin{array}{l}\text { 1. Hard point } \\
\text { including } 2.5 \mathrm{~km} \\
\text { revetment } \\
\text { (Sirajgonj) } \\
\end{array}$ & $\begin{array}{l}\text { River flow directly hit and cause } \\
\text { severe bank erosion near adjacent } \\
\text { area, branch but active channel }\end{array}$ & $\begin{array}{l}\text { - Flow hit at hard point } \\
\text { and diverted } \\
\text { - Erosion reduce }\end{array}$ & $\begin{array}{l}\text { Jamuna River, Sirajgonj } \\
\text { Town, Low land } \\
\text { floodplain with small } \\
\text { channel } \\
\end{array}$ & $\begin{array}{l}\text { Jamuna River, Sirajgonj } \\
\text { Town, destruction of low } \\
\text { land floodplain with small } \\
\text { channel }\end{array}$ & $\begin{array}{l}\text { Large amount of fishes } \\
\text { found earlier in Jamuna } \\
\text { River and adjacent } \\
\text { floodplain area } \\
\end{array}$ & \begin{tabular}{|l} 
Fish production \\
decreased due to \\
destruction of \\
floodplain area \\
\end{tabular} \\
\hline $\begin{array}{l}\text { 2. Revetment } \\
\text { with concrete } \\
\text { block (Titporal) }\end{array}$ & $\begin{array}{l}\text { River flow directly hit and cause } \\
\text { sever bank erosion near adjacent } \\
\text { area, branch channel }\end{array}$ & $\begin{array}{l}\text { - Flow divert } \\
\text { - Erosion reduce }\end{array}$ & \begin{tabular}{|l|} 
Bogra, Bangali River, \\
Jamuna River, flood \\
plain area
\end{tabular} & $\begin{array}{l}\text { Prevent merger of Jamuna } \\
\text { and Bangali River }\end{array}$ & $\begin{array}{l}\text { Different species of fishes } \\
\text { was naturally available }\end{array}$ & $\begin{array}{l}\text { Fish availability have } \\
\text { become lesser than } \\
\text { earlier }\end{array}$ \\
\hline $\begin{array}{l}\text { 3. Revetment } \\
\text { with Geo-bag } \\
\text { (Nakalia, Bera) }\end{array}$ & $\begin{array}{l}\text { River flow directly hit and cause } \\
\text { sever bank erosion near adjacent } \\
\text { area, branch channel }\end{array}$ & $\begin{array}{l}\text { - Flow divert } \\
\text { - Erosion reduce }\end{array}$ & $\begin{array}{l}\text { Bera-Pabna, Jamuna, } \\
\text { flood plain area }\end{array}$ & $\begin{array}{l}\text { Bera-Pabna, Jamuna, flood } \\
\text { plain area is reduce }\end{array}$ & $\begin{array}{l}\text { Different species of fishes } \\
\text { was naturally available }\end{array}$ & $\begin{array}{l}\text { Fish availability have } \\
\text { become lesser than } \\
\text { earlier }\end{array}$ \\
\hline $\begin{array}{l}\text { 4. Revetment } \\
\text { concrete block } \\
\text { (Rajshahi) }\end{array}$ & $\begin{array}{l}\text { River flow directly hit and cause } \\
\text { sever bank erosion near adjacent } \\
\text { area, main but inactive }\end{array}$ & $\begin{array}{l}\text { - Flow divert } \\
\text {-Erosion reduce }\end{array}$ & $\begin{array}{l}\text { Godagari-rajshahi, } \\
\text { Padma River, small } \\
\text { channel }\end{array}$ & $\begin{array}{l}\text { Godagari-rajshahi, Padma } \\
\text { River, small channel are } \\
\text { destroyed due to silt } \\
\text { deposition }\end{array}$ & $\begin{array}{l}\text { Different species of fishes } \\
\text { was naturally available }\end{array}$ & $\begin{array}{l}\text { Fish availability have } \\
\text { become lesser than } \\
\text { earlier }\end{array}$ \\
\hline $\begin{array}{l}\text { 5. Revetment } \\
\text { concrete block } \\
\text { (Chandpur) } \\
\end{array}$ & $\begin{array}{l}\text { River flow directly hit and cause } \\
\text { sever bank erosion near adjacent } \\
\text { area, main and active channel }\end{array}$ & $\begin{array}{l}\text { - Flow hit at hard point } \\
\text { and diverted } \\
\text { - Erosion reduce }\end{array}$ & $\begin{array}{l}\text { Padma, Meghna, } \\
\text { Chandpur Town, } \\
\text { Dhakatia River } \\
\end{array}$ & $\begin{array}{l}\text { Padma, Meghna, Chandpur } \\
\text { Town, Dhakatia River }\end{array}$ & $\begin{array}{l}\text { Different species of fishes } \\
\text { was naturally available }\end{array}$ & $\begin{array}{l}\text { No change determined } \\
\text { in the fish availability }\end{array}$ \\
\hline $\begin{array}{l}\text { 6. Groyne } \\
\text { (kalitola) }\end{array}$ & $\begin{array}{l}\text { River flow directly hit and cause } \\
\text { sever bank erosion near adjacent } \\
\text { area, branch and active channel }\end{array}$ & $\begin{array}{l}\text { - Reduced velocity of } \\
\text { water } \\
\text { - Erosion occurs at } \\
\text { adjacent downstream } \\
\end{array}$ & $\begin{array}{l}\text { Bogra, Bangali River, } \\
\text { Jamuna River }\end{array}$ & $\begin{array}{l}\text { Prevent merger of Jamuna } \\
\text { and Bangali River }\end{array}$ & $\begin{array}{l}\text { Different species of fishes } \\
\text { was naturally available }\end{array}$ & $\begin{array}{l}\text { Fish availability have } \\
\text { become lesser than } \\
\text { earlier }\end{array}$ \\
\hline $\begin{array}{l}\text { 7. RCC Spur } \\
\text { (Betil, Enayetpur) }\end{array}$ & $\begin{array}{l}\text { River flow directly hit the adjacent } \\
\text { area and erosion occurred, } \\
\text { branch and active channel }\end{array}$ & $\begin{array}{l}\text { - Reduced velocity of } \\
\text { water } \\
\text { - Erosion observed in } \\
\text { adjacent char land-New } \\
\text { arable land rise }\end{array}$ & $\begin{array}{l}\text { Jamuna River, } \\
\text { Enayetpur, Betil }\end{array}$ & $\begin{array}{l}\text { Jamuna River, } \\
\text { Enayetpur, Betil }\end{array}$ & $\begin{array}{l}\text { Different species of fishes } \\
\text { was naturally available }\end{array}$ & $\begin{array}{l}\text { Fish decrease, Small } \\
\text { fishes found beside } \\
\text { Spur }\end{array}$ \\
\hline $\begin{array}{l}\text { 8. RCC Spur } \\
\text { (Panka } \\
\text {-Narayanpur) }\end{array}$ & $\begin{array}{l}\text { River flow directly hit and cause } \\
\text { sever bank erosion near adjacent } \\
\text { area, main and inactive channel }\end{array}$ & $\begin{array}{l}\text { - Reduced velocity of } \\
\text { water } \\
\text { - Erosion observed in } \\
\text { adjacent main land and } \\
\text { spur site }\end{array}$ & $\begin{array}{l}\text { Padma River, } \\
\text { Chapai-Nawabgonj } \\
\text { Sadar, floodplain area }\end{array}$ & $\begin{array}{l}\text { Padma River, } \\
\text { Chapai-Nawabgonj Sadar }\end{array}$ & $\begin{array}{l}\text { Different species of fishes } \\
\text { was naturally available }\end{array}$ & $\begin{array}{l}\text { Fish availability have } \\
\text { become lesser than } \\
\text { earlier }\end{array}$ \\
\hline 9. Bandals & $\begin{array}{l}\text { Branch channel, erosion occurs and } \\
\text { destroy productive agricultural land }\end{array}$ & $\begin{array}{l}\text { - Reduced velocity of } \\
\text { water } \\
\text { - Flow diverted. } \\
\text { - Channel formed in } \\
\text { adjacent area }\end{array}$ & $\begin{array}{l}\text { Jamuna River, } \\
\text { Madumoti River at } \\
\text { downstream }\end{array}$ & $\begin{array}{l}\text { Jamuna River, Madumoti } \\
\text { River at downstream }\end{array}$ & $\begin{array}{l}\text { Different species of fishes } \\
\text { was naturally available }\end{array}$ & $\begin{array}{l}\text { No change determined } \\
\text { in the fish availability }\end{array}$ \\
\hline
\end{tabular}


Table 5 Integrated matrix.

\begin{tabular}{|c|c|c|c|c|c|c|c|c|c|c|}
\hline \multirow[b]{2}{*}{$\begin{array}{l}\text { Type of } \\
\text { structures }\end{array}$} & \multicolumn{3}{|c|}{ A. (technical stability) } & \multicolumn{3}{|c|}{ B. (river stability) } & \multirow[b]{2}{*}{ C. (failure causes) } & \multicolumn{3}{|c|}{ D. (social acceptability) } \\
\hline & $\begin{array}{l}\text { Erosion } \\
\text { threat }\end{array}$ & \begin{tabular}{|l|} 
Protection \\
Safety
\end{tabular} & $\begin{array}{l}\text { Local availability } \\
\text { (skilled labor, } \\
\text { cons. mat.) }\end{array}$ & $\begin{array}{l}\text { Hydraulic and } \\
\text { hydrological }\end{array}$ & Connectivity & $\begin{array}{l}\text { Ecological and } \\
\text { environmental }\end{array}$ & & Risks & Livelihood & Poverty \\
\hline $\begin{array}{l}\text { 1. Hard point } \\
\text { including } 2.5 \mathrm{~km} \\
\text { revetment } \\
\text { (Sirajgonj) }\end{array}$ & Medium & High & Not available & $\begin{array}{l}\text { - Flow hits at hard point } \\
\text { and gets diverted } \\
\text { - Erosion decreased }\end{array}$ & \begin{tabular}{|l} 
Jamuna River, \\
Sirajgong Town, \\
destruction of Low \\
land floodplain with \\
small channel \\
\end{tabular} & $\begin{array}{l}\text { Different species of } \\
\text { fishes lesser due to } \\
\text { destruction of } \\
\text { floodplain area }\end{array}$ & $\begin{array}{l}\text { Local scouring, } \\
\text { Mass failure }\end{array}$ & Medium & $\begin{array}{l}\text { Increased in } \\
\text { transport and } \\
\text { business sector }\end{array}$ & Low \\
\hline \begin{tabular}{|l|} 
2. Revetment \\
with concrete \\
block (Titporal) \\
\end{tabular} & Medium & High & Not available & $\begin{array}{l}\text { - Flow divert } \\
\text {-Erosion decreased }\end{array}$ & \begin{tabular}{|l|} 
Prevent merger of \\
Jamuna and Bangali \\
River
\end{tabular} & \begin{tabular}{|l|} 
Fish availability \\
have become lesser \\
than earlier
\end{tabular} & \begin{tabular}{|l} 
Local scouring, \\
mass failure
\end{tabular} & Medium & \begin{tabular}{|l}
$\begin{array}{l}\text { Increasing in } \\
\text { business, } \\
\text { agriculture sector }\end{array}$ \\
\end{tabular} & Low \\
\hline $\begin{array}{l}\text { 3. Revetment } \\
\text { with Geo-bag } \\
\text { (Nakalia, Bera) }\end{array}$ & Low & High & Available & $\begin{array}{l}\text { - Flow divert } \\
\text {-Erosion decreased }\end{array}$ & \begin{tabular}{|l} 
Bera-Pabna, \\
Jamuna. Flood plain \\
area are reduce
\end{tabular} & $\begin{array}{l}\text { Different species of } \\
\text { fishes was naturally } \\
\text { available }\end{array}$ & Floodplain erosion & Low & $\begin{array}{l}\text { Increasing in } \\
\text { business sector }\end{array}$ & Medium \\
\hline $\begin{array}{l}\text { 4. Revetment } \\
\text { concrete block } \\
\text { (Rajshahi) }\end{array}$ & Medium & Medium & Partly available & $\begin{array}{l}\text { - Flow divert } \\
\text {-Erosion decreased }\end{array}$ & $\begin{array}{l}\text { Godagari-rajshahi, } \\
\text { Padma River, small } \\
\text { channel are destroy } \\
\text { due to deposition } \\
\end{array}$ & $\begin{array}{l}\text { Fish availability } \\
\text { have become lesser } \\
\text { than earlier }\end{array}$ & $\begin{array}{l}\text { Floodplain erosion, } \\
\text { Local scouring }\end{array}$ & Medium & Agriculture, service & Low \\
\hline $\begin{array}{l}\text { 5. Revetment } \\
\text { concrete block } \\
\text { (Chandpur) }\end{array}$ & Low & High & Partly available & $\begin{array}{l}\text { - Flow hit at hard point and } \\
\text { diverted } \\
\text {-Erosion decreased }\end{array}$ & $\begin{array}{l}\text { Padma, Meghna, } \\
\text { Chandpur Town, } \\
\text { Dhakatia River }\end{array}$ & $\begin{array}{l}\text { No change } \\
\text { determined in the } \\
\text { fish availability }\end{array}$ & $\begin{array}{l}\text { Local scouring, } \\
\text { Mass failure }\end{array}$ & Medium & $\begin{array}{l}\text { Increasing in } \\
\text { fisheries sector }\end{array}$ & Medium \\
\hline $\begin{array}{l}\text { 6. Groyne } \\
\text { (kalitola) }\end{array}$ & Medium & High & Not available & \begin{tabular}{|l|} 
- Reduced velocity of \\
water \\
- Erosion occurs at \\
adjacent downstream \\
\end{tabular} & $\begin{array}{l}\text { Prevent merger of } \\
\text { Jamuna and Bangali } \\
\text { River }\end{array}$ & $\begin{array}{l}\begin{array}{l}\text { Fish availability } \\
\text { have become lesser } \\
\text { than earlier }\end{array} \\
\end{array}$ & $\begin{array}{l}\text { Local scouring, } \\
\text { mass failure, } \\
\text { Withdraw of sand } \\
\text { from sub-surface }\end{array}$ & Medium & $\begin{array}{l}\text { Changed from } \\
\text { agricultural to } \\
\text { agricultural labor }\end{array}$ & Low \\
\hline $\begin{array}{l}\text { 7. RCC Spur } \\
\text { (Betil, Enayetpur) }\end{array}$ & High & High & Partly available & $\begin{array}{l}\text { - Reduced velocity of } \\
\text { water } \\
\text { - Erosion observed in } \\
\text { adjacent char land } \\
\text { - New arable land accreted } \\
\end{array}$ & $\begin{array}{l}\text { Jamuna River, } \\
\text { Enayetpur, Betil }\end{array}$ & $\begin{array}{l}\text { Fish production } \\
\text { decrease, small size } \\
\text { of fishes is found } \\
\text { beside Spur }\end{array}$ & Local scouring & Low & $\begin{array}{l}\text { Handloom, } \\
\text { business }\end{array}$ & Low \\
\hline $\begin{array}{l}\text { 8. RCC Spur } \\
\text { (Panka } \\
\text {-Narayanpur) }\end{array}$ & High & Poor & Partly available & $\begin{array}{l}\text { - Reduced velocity of } \\
\text { water } \\
\text { - Erosion observed in } \\
\text { adjacent main land and } \\
\text { spur site } \\
\end{array}$ & $\begin{array}{l}\text { Padma River, } \\
\text { Chapai-Nawabgonj } \\
\text { Sadar }\end{array}$ & $\begin{array}{l}\text { Fish availability } \\
\text { have become lesser } \\
\text { than earlier }\end{array}$ & $\begin{array}{l}\text { Local scouring, } \\
\text { Floodplain erosion }\end{array}$ & Low & $\begin{array}{l}\text { Changed from } \\
\text { agricultural to } \\
\text { agricultural labor }\end{array}$ & Medium \\
\hline 9. Bandals & High & low & available & $\begin{array}{l}\text { - Reduced velocity of } \\
\text { water -Flow diverted } \\
\text { - Channel formed in } \\
\text { adjacent area }\end{array}$ & $\begin{array}{l}\text { Jamuna River, } \\
\text { Madumoti River at } \\
\text { downstream }\end{array}$ & $\begin{array}{l}\text { No change } \\
\text { determined in the } \\
\text { fish availability }\end{array}$ & $\begin{array}{l}\text { Flow hit directly, } \\
\text { Floodplain erosion }\end{array}$ & Medium & $\begin{array}{l}\text { Opportunities } \\
\text { create on } \\
\text { agricultural sector }\end{array}$ & Medium \\
\hline
\end{tabular}


upon the stability of the bank protection works, which again depends upon the faith of the local people on structure. The local people are capable to play a vital role in the management of any emerging disaster. So, the community involvement is necessary for the management of such activities like construction of any river training works. It is noted that before taking any bank protection project, the societal needs and demands should be taken into consideration. It could be more fruitful and sustain as a whole for the societal wellbeing of the locality. The riverine people also suggested that the suitable time for construction of any river training works is in dry season. Implementation cost gets minimized due to cheap labor cost, because in dry season riverine people may get less work opportunity. A technically suitable structure may not have good social acceptance, which makes the evaluation considering all aspects very difficult. Therefore, a detailed study could give a better answer. In this study, all these issues (technical evaluation and ecological functioning) measures qualitative during focus group discussion, which need to be evaluated quantitatively, are not being explored in detail. Technical and natural analysis for preparation of integrated matrix is shown in Tables 3-5.

\section{Conclusions}

River plays the vital role in socio-economic of the country. River bank and bed scour associated with channel confluences and bends. Bank materials of the major rivers are mainly consisted of non-cohesive sediment such as sand, silt and a small amount of clay, which is highly susceptible to erosion. For the prevailing hydro-morphological characteristics of the major rivers performances of the structures are evaluated considering different aspects, such as stability, cost, safety and eco-friendly. From technical point of view, stability of the structure in the hydro-morphological condition of the river comes first. In this regard, hard point at Sirajganj, protection work at Chandpur and revetment work at Nakalia are found to be suitable. But the cost of hard point at Siranganj is very high where that of revetment at Nakalia is relatively cheaper. There are other low cost structures such as spurs at Betil-Enayetpur and Bandals. But these structures highly fragile to the normal strength of the flow of the braided channel. This structure could be put provisionally on very small braided channels to protect the less intensive erosion along those channels. A technically suitable structure may not have good social acceptance, which makes the evaluation considering all aspects is very difficult. Socio-economic and environmental consideration, river behavior and morphological features need to be clarified along the river systems. Land and water management should not be a stand-alone policy but rather an integrated way.

\section{Acknowledgments}

The authors express their gratitude to Mohammad Arifur Rahman, Mahmud Hasan Tuhin, Dr. Sujit Kumar Bala, CEGIS (Center for Environmental and Geographic Information Services) and IWM (Institute of Water Modeling) to provide their technical and financial support for this study.

\section{References}

[1] K.M. Elahi, Riverbank Erosion, Flood Hazard and Population Displacement in Bangladesh: An Overview, Riverbank Erosion Impact Study, Jahangirnagar University, USA, 1991, pp. 95-110.

[2] A.H. Chowdhury, M. Kabir, Socioeconomic and Demographic Characteristics of Displaces in Bhola and Kazipur: A Comparative Study, Riverbank Erosion Impact Study, Jahangirnagar University, 1991, pp. 111-122.

[3] M.N. Uddin, M.D.M. Rahman, Flow and erosion processes at bends and around river training works in a sand bed braided river, Ph.D. Thesis, Bangladesh University of Engineering and Technology, 2010.

[4] T. Nakagawa, J.C. Scott, Stream meanders on a smooth hydrophobic surface, Journal of Fluid Mechanics 149 (1984) 89-99.

[5] FAP 1 (Flood Action Plan), in: Proceedings of the Third Conference, Water Development and Flood Control/Flood Plan Coordination Organization (FPCO), Ministry of Irrigation, Dhaka, Bangladesh, May 17-20, 1993.

[6] FAP 24, Morphological Characteristics, River Survey 
Project, Annex 5, BWDB (Bangladesh Water Development Board), 1996.

[7] Guidelines for Riverbank Protection, Jamuna-Meghna River Mitigation Project (JMREMP), BUET (Bangladesh University of Engineering and Technology), Bangladesh, 2008.

[8] Bank Protection and River Training, Consulting Consortium, AFPM (advanced fluid physics module) pilot project, FAP 21/22, 1993.

[9] CEGIS Prediction of River Bank Erosion along the Jamuna, the Ganges and the Padma Rivers in 2010, Jamuna-Meghna River Erosion Mitigation Project, Bangladesh Water Development Board, Dhaka, 2010.
[10] Guideline to Planning and Design of River Training and Bank Protection Works, Bangladesh Water Development Board, Dhaka, Bangladesh, 1993.

[11] Guidelines and Design Manual for Standardized Bank Protection Structures, Jamuna Test Works Consultants, Joint Venture, 2001.

[12] C.E. Haque, Hazards in a Fickle Environment: Bangladesh, Kluwer Academic Publishers, The Netherlands, 1997.

[13] J.M. Coleman, Brahmaputra River: Channel processes and sedimentation, Sedimentary Geology 3 (1969) 129-239.

[14] Guidelines for River Bank Protection, Bangladesh Water Development Board and BUET, Dhaka, Bangladesh, 2008. 